\title{
PEMANFAATAN NIRA AREN (Arenga pinnata Merr) SEBAGAI BAHAN PEMBUATAN GULA PUTIH KRISTAL
}

\author{
The Useful Nira Aren (Arenga pinnata Merr) as Raw Material for Making White Refined Sugar
}

Baharuddin, Musrizal Muin, dan Herniaty Bandaso

\begin{abstract}
A research was conducted to evaluate the quality of white refined sugar produced from palm tree (Arenga pinnata) using direct and indirect cooking processes. Visual methods were applied to determine color, shape and texture of produced sugar. The sucrose, ash, and other sugar contents as well as dry weight of produced refined sugar were also analyzed. Results showed that the production process using direct cooking resulted in small granulated, dry, compacted and milky white refined sugar, while that using indirect cooking (four hours storage) produced clay granulated, less compacted, dust shape and browning refined sugar. The sucrose, ash, and other sugar contents found in direct cooking process were $10.27 \%$, $0.016 \%$. and $2.68 \%$, respectively, while those found in indirect cooking process were $11.11 \%, 0.018 \%$, and $2.78 \%$, respectively.
\end{abstract}

Key words: Palm tree, Arenga pinnata, nira, white refined sugar

\section{PENDAHULUAN}

Hasil hutan bukan kayu di Indonesia sudah sejak lama menjadi komponen penting dan dimanfaatkan oleh masyarakat sekitar hutan walaupun pada umumnya masih merupakan kegiatan musiman atau sambilan saja. Departemen Kehutanan melaporkan bahwa pengelolaan hasil hutan bukan kayu mempunyai peranan yang cukup besar dalam perekonomian bangsa yaitu 30 juta penduduk "secara langsung mengandalkan hidupnya pada sektor kehutanan yaitu mengambil dan mengelola hasil hutan bukan kayu" sebagai mata pencaharian dan sebagai wadah penyerap tenaga kerja. Pertambahan jumlah penduduk yang besar menyebabkan kebutuhan pokok semakin meningkat termasuk kebutuhan pangan berupa gula. Besarnya peranan gula dalam kehidupan sehari-hari dan bidang industri, menyebabkan kebutuhan akan gula terus meningkat. Menurut Musa dan Mursalim (2007), total kebutuhan gula nasional tahun 2006 mencapai 2,3 juta ton. Peningkatan tersebut akan terus bertambah dengan bertambahnya jumlah penduduk, meningkatnya pendapatan dan berkembangnya industri yang menggunakan gula sebagai bahan baku utamanya. Untuk menanggulangi masalah tersebut maka perlu diadakan diversifikasi bahan baku gula yang lebih murah dan mudah, terutama dari tanaman non tebu.

Nira adalah cairan yang manis yang diperoleh dari air perasan batang atau getah tandan bunga tanaman seperti tebu, bit, sorgum, mapel, siwalan, bunga dahlia dan tanaman dari keluarga Palma seperti aren, kelapa, nipah, sagu, kurma dan sebagainya.

Nira aren merupakan salah satu sumber bahan pangan dalam pembuatan gula. Pohon aren umumnya dijumpai tumbuh secara liar (tidak ditanam orang) Hampir semua bagian dari pohon ini dapat dimanfaatkan dan memiliki nilai ekonomi mulai dari bagian-bagian fisik pohon maupun dari hasil-hasil produksinya. Ketersediaan sumberdaya tersebut juga merata di seluruh Indonesia seperti Sulawesi Selatan yang memiliki potensi Aren yang cukup besar. Secara tradisional, masyarakat mengolah nira aren menjadi gula batu (gula merah) atau gula semut yang berupa kristal. Selain itu, gula aren mempunyai banyak kelebihan seperti harganya yang jauh lebih tinggi dan aromanya yang lebih harum. Namun pemanfaatan nira aren menjadi gula putih kristal belum dilakukan. Penelitian ini dilakukan untuk mengembangkan proses produksi nira aren menjadi gula putih kristal dan mengetahui kualitas gula putih kristal aren yang dihasilkan dari nira 
yang dimasak langsung dengan yang mengalami proses penyimpanan.

\section{BAHAN DAN METODE}

\section{Pengambilan Sampel}

Pengambilan sampel nira hasil sadapan dilakukan pagi hari sebanyak 2 liter. Sampel nira dibagi menjadi 2 bagian, bagian pertama langsung dimasak kemudian bagian kedua disimpan pada tempat steril dengan lama penyimpanan 4 jam.

\section{Pembuatan Gula Kristal}

Mengukur $\mathrm{pH}$ nira dan menetralkannya menjadi $\mathrm{pH}$ netral 7,0 dengan menambahkan kapur dan dilakukan pengadukan untuk mencegah penggumpalan. Menyaring nira untuk mengeluarkan sisa-sisa kapur setelah larut. Memasak nira pada suhu $60^{\circ} \mathrm{C}$. Pada saat nira mulai encer, dilakukan pengadukan agar sampel tidak menggumpal. Pemasakan dihentikan pada saat nira telah mencapai puncak kekentalan atau ditandai dengan munculnya seperti benangbenang kecil pada saat nira diplintir. Menambahkan bibit gula 50 gram yang telah dicampur dengan alkohol $70 \%$ sebanyak $1 \mathrm{ml}$. Sampel kemudian didinginkan dengan cara diangin-anginkan di wadah cawan petri dengan tebal setipis mungkin untuk mempecepat pengeringan. Dilanjutkan dengan pengeringan dengan menggunakan Freeze Drying sampai kering.

\section{Analisis Data}

Analisis data dilakukan secara deskriptif dengan pengamatan secara visual untuk warna, bentuk dan tekstur, sedangkan pengujian kualitas lainnya meliputi: rendemen, warna larutan dengan spektrofotometer, susut pengering, gula pereduksi, dan kadar abu.

\section{HASIL DAN PEMBAHASAN}

Hasil Pengamatan Secara Visual dan Pengujian Kualitas Gula Kristal Aren yang dihasilkan dari nira yang tidak mengalami penyimpanan (pemasakan langsung) dan pentimpana nira selama 4 jam dapat dilihat pada Tabel 1.

\section{Bentuk, Warna dan Tekstur}

Gula yang dihasilkan pada proses pemasakan langsung berbentuk kristal (butiran kecil) yang kering, padat dan berwarna putih susu. Sedangkan pada proses penyimpanan, dihasilkan gula berbentuk kristal namun bentuknya agak liat, kurang padat, berbentuk serbuk dan berwarna gelap (agak coklat). Adanya perbedaan gula yang dihasilkan setelah proses penyimpanan, diakibatkan oleh adanya proses fermentasi telah berlangsung. Nira yang mengalami proses penyimpanan ditumbuhi bakteri dan jamur sehingga akan mempengaruhi bahan baku dan produk yang dihasilkan. Hal ini sesuai dengan pendapat Sardjono, dkk. (1985) bahwa bakteri dan jamur dalam nira yang telah terfermentasi, akan tumbuh dan berkembang lebih baik sehingga proses kerusakan lebih cepat dan meyebabkan gula menjadi lumer dan cepat berjamur karena basah. Keterlambatan pemasakan, kandungan garam dan penambahan bahan tertentu akan terbentuk gula yang menjadi liat, tidak padat dan berwarna coklat tua. Wadah yang digunakan untuk penyimpanan juga berpengaruh sehingga harus bebas dari kontaminasi, karena jika terkombinasi maka akan terjadi proses fermentasi atau perombakan terhadap senyawa-senyawa penyusunnya di mana sukrosa berubah menjadi

Table 1. White refined sugar from palm tree (Arenga pinnata) using directand indirect cooking processes

\begin{tabular}{|c|c|c|}
\hline \multicolumn{3}{|c|}{ Treatment } \\
\hline & Direct cooking process & $\begin{array}{c}\text { Indirect cooking process (storage } \\
\text { until four hour) }\end{array}$ \\
\hline Shape, color, and texture & $\begin{array}{l}\text { small granulated and dry, } \\
\text { compacted, and milky white }\end{array}$ & $\begin{array}{l}\text { Clay granulated, less compacted, } \\
\text { dust shape, and darkly (browning). }\end{array}$ \\
\hline Sucrose content of sugar (\%) & 10,27 & 11.11 \\
\hline Ash (\%) & 0.016 & 0.018 \\
\hline The other sugars (\%) & 2.68 & 2.78 \\
\hline Color (absorption solution) & 4859 & 5881 \\
\hline Reduce weight for dry & 2.6 & 3.0 \\
\hline
\end{tabular}


alkohol dan berubah lagi menjadi asam asetat (Bandini, 1996). Bila nira dibiarkan beberapa waktu tanpa adanya usaha pengawetan, maka akan timbul perubahan kimia dan fisik. Perubahan ini disebabkan oleh adanya aktivitas mikroorganisme (enzim) terhadap kandungan sukrosa (Lutony 1993).

\section{Rendemen}

Besarnya rendemen gula kristal yang dihasilkan dari proses tanpa penyimpanan adalah $10,27 \%$ sedangkan pada proses penyimpanan besarnya $11,11 \%$. Perbedaan rendemen gula yang dihasilkan dipengaruhi oleh kadar air dimana nira yang telah mengalami fermentasi pada penyimpanan mengandung banyak air sehingga rendemen yang dihasilkan lebih berat. Gula yang dihasilkan pada proses penyimpanan bertekstur sedikit liat dibanding gula pada proses pemasakan langsung. Bentuk gula yang agak liat mempengaruhi berat yaitu air yang berada dalam gula sulit untuk dilepaskan. Hal ini sesuai dengan pendapat yang dikemukakan oleh Sardjono, dkk. (1985) bahwa bahan baku berpengaruh terhadap kualitas. Nira yang telah terfermentasi mengakibatkan hilangnya pektin dan protein dalam nira akibatnya kadar airnya meningkat sehingga gula menjadi liat dan cepat gosong. Selain itu, keterlambatan pemasakan akan membentuk gula yang menjadi liat. Menurut Buckle, et al. (1978), inversi sukrosa menyebabkan berkurangnya hasil dan kadar air yang tinggi pada produk akhir dimana invers sukrosa dapat mengakibatkan rendemen produksi menjadi rendah, gula reduksi tinggi dan kadar air yang tinggi. Jika dibandingkan dengan produksi gula merah yaitu $5 \mathrm{~kg} / 20$ liter, gula kristal yang dihasilkan lebih rendah yaitu $4 \mathrm{~kg} / 20$ liter.

\section{Kadar Abu}

Besarnya nilai kadar abu gula kristal adalah $0,016 \%$ pada proses tanpa penyimpanan dan $0,018 \%$ pada proses penyimpanan. Pada proses penyimpanan, $\mathrm{pH}$ nira mulai berubah menjadi asam yaitu mencapai $\mathrm{pH} 5$, adanya proses fermentase oleh mikroorganisme telah ada dalam nira yang juga menyebabkan kadar air meningkat namun pemanfaatan mineral akan menyebabkan menurunnya kadar abu. Akan tetapi penambahan kapur tohor untuk menetralkan kembali nira pada saat $\mathrm{pH}$ nira turun menjadi 5 juga mempengaruhi meningkatnya kandungan mineral. Hal ini sesuai dengan pendapat yang dikemukakan oleh Somaatmadja (1980) bahwa kadar abu dalam gula sangat dipengaruhi oleh kandungan mineral dalam nira serta pada proses pembuatannya. Kandungan mineral yang ada dalam nira mulai berkurang dan tergantikan oleh air pada saat penyimpanan, begitupun pada saat gula disimpan. Perubahan sukrosa yang terjadi selama penyimpanan juga mempengaruhi. Semakin rendah kadar abu gula, semakin bagus kualitasnya dan sebaliknya.

\section{Gula Pereduksi}

Besarnya nilai gula pereduksi berdasarkan hasil pengujian adalah 2,68 \% pada proses tanpa penyimpanan dan 2,78 \% pada psoses penyimpanan. Tingginya gula pereduksi ini dipengaruhi oleh adanya proses fermentasi yang terjadi dan meningkatnya kadar air. Kadar air pada proses penyimpanan lebih tinggi daripada proses pemasakan langsung. Pengaruh musim juga menjadi penyebab tingginya nilai gula pereduksi karena nira yang digunakan diambil pada musim hujan sehingga kadar airnya tinggi dan kadar gulanya rendah. Hal ini sesuai dengan pendapat yang dikemukakan oleh Sardjono, dkk. (1985) bahwa kenaikan kadar gula reduksi terjadi sejalan dengan kenaikan kadar air selama penyimpanan dan proses fermentasi yang terjadi. Semakin rendah nilai gula reduksi semakin bagus kualitas gula tersebut.

Menurut Buckle, et al. (1978), inversi sakarosa menyebabkan berkurangnya hasil dan kadar air yang tinggi pada produk akhir di mana inversi sakarosa dapat mengakibatkan rendemen produksi menjadi rendah, kadar gula reduksi tinggi dan kadar air yang tinggi. Kadar gula pereduksi mempengaruhi kekerasan, warna dan rasa gula di mana makin rendah kadar gula pereduksi makin coklat kekuningan (terang) warna gulanya (Sardjono, dkk. 1985), sebaliknya makin tinggi kadar gula pereduksi makin gelap warna gula, disebabkan karena terjadi reaksi maillard (browning) yang menghasilkan senyawa berwarna coklat pada gula (Winarno, 1984).

\section{Warna larutan}

Besarnya nilai warna larutan berdasarkan hasil pengujian adalah 4859 pada proses tanpa penyimpanan dan 5881 pada psoses penyimpanan. Tingginya warna larutan gula yang dihasilkan dipengaruhi oleh musim, $\mathrm{pH}$ nira pada 
saat pemasakan, penambahan kapur untuk menetralkan nira dan cara pamasakan gula. Pengambilan sampel yang dilakukan pada musim hujan membuat nira lebih kotor karena tetesan air hujan, kotoran lain seperti serangga yang masuk ke dalam bumbung dan bercampur dengan nira. Penggunaan bahan dan alat juga dapat mempengaruhi warna. Selain itu, proses pemasakan yang tidak stabil dengan suhu yang tidak dapat dikontrol dan penambahan kapur pada nira yang telah terfermentasi juga mempengaruhi warna larutan karena adanya bahan tambahan lain dalam nira. Hal ini sesuai dengan pendapat Samarajewa dan Wijeratne (1979) bahwa nira yang dihasilkan pada musim hujan lebih tinggi dibanding musim panas tetapi lebih kotor karena tetesan air hujan, hama dan ulat yang lebih banyak mengakibatkan hasil gula pun kurang baik dan kurang bersih. Penambahan bahan tertentu mempengaruhi kualitas nira.

\section{Susut pengeringan}

Besarnya nilai susut pengeringan berdasarkan hasil pengujian adalah 2,6\% pada proses tanpa penyimpanan dan $3,0 \%$ pada psoses penyimpanan. Pengujian susut pengeringan dilakukan untuk melihat kadar air dan mengetahui pengurangan bobot setelah dikeringkan pada waktu dan suhu yang ditetapkan. Tingginya nilai susut pengeringan disebabkan karena dalam proses penyimpanan terjadi peningkatan kadar air oleh adanya proses fermentasi dan gula yang dihasilkan bersifat lebih higroskopis. Hal ini sesuai dengan pendapat Samarajewa dan Wijeratne (1979) bahwa gula bersifat higroskopis sehingga semakin lama disimpan, kadar airnya semakin tinggi.

\section{KESIMPULAN}

Berdasarkan hasil penelitian pembuatan dan pengujian gula kristal dari nira aren yang dilakukan, maka dapat diperoleh kesimpulan sebagai berikut :

Diterima : 11 April 2007

Baharuddin

Lab. Keteknikan dan Diversifikasi Produk Hasil Hutan

Fakultas Kehutanan, Universitas Hasanuddin

Kampus Tamalanrea, Jl. Perintis Kemerdekaan Km. 10, Makassar 90245

Telp./Fax. 0411-585917. Indonesia
1. Nira aren yang langsung diolah lebih baik kualitasnya dibanding nira yang telah mengalami proses penyimpanan.

2. Rendemen gula yang dihasilkan dari proses penyimpanan lebih banyak tetapi kualitas yang dihasilkan lebih baik pada proses tanpa penyimpanan.

\section{DAFTAR PUSTAKA}

Bandini, Y. 1996. Nipah Pemanis Alami Baru. Penebar Swadaya. Jakarta.

Buckle, K.A., R.A. Edwards, H. Fleet, dan M. Wootton. 1987. Ilmu Pangan (terjemahan). Universitas Hasanuddin Press. Jakarta.

Departemen Kehutanan. 1996. Materi Penyuluhan I. Pusat Penyuluhan Kehutanan. Makassar.

Fardiaz, S., F.G. Winarno, dan F. Dedi. 1980. Pengantar Teknologi Pangan. PT Gramedia. Jakarta.

Lutony, T.L. 1993. Tanaman Sumber Pemanis. Penebar Swadaya. Jakarta.

Samarajewa, U. dan M.C. Wijeratne. 1979. Methods for Determiding Suitability of Coconut Sap for Preparation of Jagery, Sugar and Golden Syrup. Ceylon Coconut Quarterly: 7280.

Sardjono, E.A. Basrah, dan O. Sukardi. 1985. Penelitian dan Pengembangan Diversifikasi Produk dan Pengepakan Gula Merah Cetak. Bogor.

Sastroamidjojo, 1988. Obat Asli Indonesia. PT Dian Rakyat, Sari Pustaka Universitas. Jakarta.

Somaatmadja, D. 1980. Ketela sebagai Bahan Pembuatan Gula. Buletin Perhimpunan Ahli Teknologi Pangan Indonesia, (5).

Winarno, F.G. 1984. Kimia Pangan dan Gizi. PT. Gramedia. Jakarta. 